\title{
Silviculture and wildlife relationships in the boreal forest of Interior Alaska ${ }^{1}$
}

\author{
by D. A. Haggstrom ${ }^{1}$ and D. G. Kelleyhouse ${ }^{3}$
}

\begin{abstract}
Wildlife diversity and abundance are directly tied to the ever changing nature of the boreal forest. Wildland fire and fluvial action have been primarily responsible for maintaining diversity and productivity. However, there is an increasing need to protect people, human developments and a forest base for timber harvest from natural disturbances. Differences between logging, prescribed fire and wildland fire, and their effects on wildlife are discussed. We also discuss the value of riparian and late successional forest types within the boreal forest, our concerns for proposals that seek to optimize timber harvests for large areas, and some professional, political, economic and biological challenges facing managers who attempt to supplement or supplant natural processes with silvicultural practices. We conclude by urging forest managers to make decisions carefully, based on the best environmental science available, with full public and agency involvement, and with the understanding that there is still much to be learned about the boreal forest ecosystem.
\end{abstract}

Key words: boreal forest, wildlife, wildland fire, clearcut logging, old growth
La diversité et l'abondance de la faune sont directement liées à la nature sans cesse changeante de la forêt boréale. Les feux hors contrôle et l'action des eaux courantes ont été principalement responsables du maintien de la biodiversité et de la productivité. Cependant, il est de plus en plus nécessaire de protéger des perturbations naturelles les gens, les constructions humaines et une base forestière pour la récolte de matière ligneuse. Les différences entre l'exploitation forestière, le brûlage dirigé et les feux hors contrôle, ainsi que leurs effets sur la faune sont discutés dans cet article. Nous abordons également la valeur des types de forêts riveraines et de la fin du cycle climacique que l'on retrouve dans le milieu boréal; nos inquiétudes face aux propositions qui cherchent à optimiser la récolte de la matière ligneuse sur de grandes étendues; et certains des défis professionnels, politiques et biologiques qui font face aux gestionnaires qui tentent de compléter ou de supplanter les processus naturels par des pratiques sylvicoles. Nous concluons en incitant les gestionnaires forestiers à prendre leurs décisions avec soins, selon la meilleure information scientifique disponible sur l'environnement, en faisant participer pleinement le public et les organismes du milieu, et en comprenant qu'il reste encore beaucoup à apprendre sur l'écosystème forestier boréal.

Mots clés: forêt boréale, faune, feu hors contrôle, exploitation par coupe à blanc, vieille forêt.
Wildlife diversity and abundance in the boreal forest are directly influenced by the diverse and dynamic pattern of seral vegetative types and ages, and habitat inter-associations. Highly mobile wildlife species commonly move to other areas as the habitat mosaic changes with forest succession or disturbance. Less mobile species become locally abundant when conditions are favorable and decline when they are not. From a wildlife manager's perspective, disturbance must be retained in the boreal forest to maintain vegetative diversity, so that wildlife diversity, abundance and productivity can also be maintained.

Historically, fire and fluvial action have been primarily responsible for maintaining the diversity and productivity of the boreal forest (Viereck 1973). Recurring wildland fires burning under widely varying conditions have created a rich mosaic of seral types. Both the oldest and youngest vegetative types commonly occur along the major rivers. Where water flow precludes formation of permafrost, older white spruce (Picea glauca) forests can develop. However, the same water flow that allows the development of old white spruce forest also con-

\footnotetext{
${ }^{1}$ A paper presented at the Silviculture, Forest Ecology and Genetics technical session at the Society of American Foresters and Canadian Institute of Forestry National Convention held at Anchorage, Alaska, on 18-22 September 1994. ${ }^{2}$ Alaska Department of Fish and Game, Division of Wildlife Conservation, 1300 College Road, Fairbanks, AK 99701.

${ }^{3}$ Alaska Department of Fish and Game, Division of Wildlife Conservation, 1300 College Road, Fairbanks, AK 99701.
}

tinually erodes some banks with mature spruce forest, depositing silt on bars where willows (Salix sp.) and poplar (Populus balsamifera) become established. This natural proximity of young, middle-aged and old growth vegetation makes riparian areas some of the most productive for wildlife in the boreal forest.

Effective fire detection and suppression efforts in Interior Alaska during the 1960s, 70s and early 80 s affected forest diversity and productivity, and, hence, wildlife diversity and abundance (Kelleyhouse 1979). Most lightning caused fires were successfully extinguished, resulting in fewer acres being burned than would have occurred naturally (Foote 1983). The forests of Interior Alaska began to age and lose their natural diversity. Fortunately, interagency fire management plans (Alaska Interagency Fire Management Council 1993), implemented across agency and private jurisdictions, have restored a near-natural fire regime in most sparsely populated regions of Alaska.

One of our biggest management challenges in the boreal forest occurs in the Tanana Valley of Interior Alaska, an area containing towns, roads, and a fledgling timber industry. In this area, sizable areas have been designated "off limits" for continued, natural disturbance by wildland fire. Thus, the forest cover is continually aging (Welbourn 1983). For wildlife, this means unnatural changes in habitat diversity and productivity.

Managed disturbances, such as logging and prescribed fire, will have to be used in such areas to augment or replace wildland fires. However, neither are the ecological equivalents 
of the wildland fires they must supplant or supplement. Natural fires produce diverse results because of the randomness of ignition, fuel types and varying weather conditions during any given burn (Kelsall et al. 1977).

From a wildlife perspective, prescribed burning is superior to logging because it involves similar physical and chemical processes to wildland fire and can be prescribed to mimic naturally occurring fire. Nonetheless, the Alaska Department of Fish and Game (ADF\&G) realizes the importance of logging and society's growing need for wood products.

Clearcut logging is often used in the boreal forest, but it is not the functional equivalent of naturally occurring fire (Hammond 1992; Mallik 1992). Considerable amounts of biomass and nutrients are removed during logging, and nutrient recycling can be quite different, depending on how slash is treated and which logging method is used.

The ADF\&G recommends that broadcast burning be conducted following clearcut logging in the boreal forest whenever possible. Burning releases a flush of nutrients, contributes to nutrient recycling, reduces soil acidity and increases the thawed active layer in permafrost areas (Kelsall et al. 1977; Viereck and Schandelmeier 1980). Growth of early successional plants preferred by early successional wildlife species can be enhanced by broadcast burns in clearcuts (ADF\&G 1991). The nutrient content of browse and berries produced following burning is higher than in those produced in unburned logged areas (Mallik 1992). One potential problem which can result on disturbed sites is the establishment of persistent stands of bluejoint (Calamagrostis canadensis) and other grasses unpalatable to wildlife (Collins 1993). More research is needed to develop post-logging treatments which will discourage establishment of persistent unpalatable grasses.

Residual standing trees are common in burns, but uncommon in clearcut areas. Fire-killed trees provide nesting cavities and insect foraging sites for woodpeckers, chickadees and other insectivorous birds, and perches for raptors and sharptailed grouse (Tympanuchus phasianellus). Leave trees or standing snags can pose unwelcome headaches for extensively mechanized logging operations, but their retention is of great benefit for some wildlife species. Another difference is that trees which are logged are not left on the ground as is the case following fire. Fallen trees provide large woody debris and hence subnivean runways and cover for small mammals and their predators such as marten (Martes americana). Wildlife diversity in logged areas would be enhanced if some standing or downed dead wood were left.

Moose (Alces alces) are an important species for many people in Interior Alaska and, therefore, have been extensively studied. Moose thrive where willows and deciduous saplings are available for browse near older forest which they use for cover. Browse production often increases greatly following clearcut logging (Telfer 1972; Vallee et al. 1976), unless purposefully suppressed to accelerate regrowth of coniferous species. Natural succession should be allowed to occur if logging is to benefit moose and other successional wildlife species.

Furbearers are also important to many people in Interior Alaska. Logging has the potential to impact various furbearer species in different ways. For instance, two of the most valuable species, marten and lynx (Lynx canadensis), generally prefer late successional and mature forest types. Both species benefit if burning or logging increases microtine rodent and showshoe hare (Lepus americanus) abundance, but both tend to avoid large openings where cover is absent. Marten and lynx are easily captured and are susceptible to overharvest where road densities are high. Logging can directly impact these species through habitat changes (Thompson 1994) and indirectly through creation of new access. Long harvest rotations, maintenance of a reasonable proportion of late successional and mature forest types within areas slated for logging, and road construction and closure policies to reduce permanent access would reduce adverse impacts of large-scale logging in the boreal forest on these species.

Red fox (Vulpes vulpes), coyotes (Canis latrans), wolverines (Gulo gulo) and wolves (Canis lupus) commonly use more open areas in the boreal forest where prey is available. Increases in vole, grouse and moose densities following logging could benefit these species as long as road densities are not excessive. Like marten and lynx, wolverines and wolves can be overtrapped in accessible areas (Mech et al. 1988).

While our knowledge of habitat requirements for moose, small game and certain furbearers is good and improving, biologists know much less about many other wildlife species of the boreal forest, such as the northern flying squirrel (Glaucomys sabrinus). For many, insufficient information is available upon which to base sound forest management recommendations. Design criteria routinely used for high profile species like moose may conflict with those needed for other species. For example, enhancement of edge effect through a pattern of small sized clearcuts has long been an accepted practice among wildlife biologists for some species, but recent research indicates the effect of openings extends further into the forest core than previously believed. As a result, creating too much edge effect can select against species requiring forest core environments (Butler 1992), such as the Townsend's warbler (Dendroica townsendi). Until more information is gained, ADF\&G recommends that clearcuts be designed with irregularly shaped borders to increase edge effect, and that well distributed, large uncut areas be retained (ADF\&G 1991).

There is a developing widespread social concern for the maintenance of "old growth" forests. Yes, there is an "old growth" component in the boreal forest, even though, at first glance, the term would seem inappropriate for a forest shaped by periodic natural disturbances. White spruce trees have the potential to live to be several hundred years old. Fires that burn surrounding black spruce (Picea marianna) forest types often stop and spot across the moist, less flammable forest environs along the rivers and on islands. Here, white spruce stands exist that are quite old.

Mature white spruce and even older poplar stands in riparian zones provide important habitat for many wildlife species. Some, like the Townsend's warbler and bald eagle (Haliaeetus leucocephalus), may have a high dependency. Bald eagles nest in large, old white spruce or poplar along Interior Alaska's rivers.

Other species, like moose, are seasonally dependent on these old riparian forests when snow depths reach critical levels (LeResche et al. 1974). The thick spruce canopy intercepts snowfall, allowing for easier movement underneath and provides thermal cover during periods of extreme temperatures. Browse is usually nearby on actively disturbed river bars or in the prickly rose (Rosa acicularis) and high-bush cranberry (Viburnum edule) understory of older poplar stands. 
Other important wildlife species which depend upon riparian areas include beaver (Castor canadensis), river otter (Lutra canadensis), and grizzly (Ursus arctos) and black (Ursus americanus) bears. In Interior Alaska, we have observed that riparian areas also serve as migration corridors for many wildlife species.

These areas are also important for timber production because they support much of the higher volume timber stands. Historically, riparian white spruce stands have produced most of the cabin logs for local residents.

Currently, uncut buffers are not required along rivers in Interior Alaska and timber harvesting may occur within $30 \mathrm{~m}$ management areas right to the river's edge. One current practice is to specifically target stands for logging that would eventually be consumed by active river bank erosion in order to salvage them for human use. The limited extent, high commercial timber value and slow natural turnover rate of mature riparian forest types causes $A D F \& G$ to be concerned about the nature and extent of future logging in these areas. ADF\&G is currently planning research to evaluate the ecological significance of late successional and mature riparian forest types so that biologists may make better informed recommendations concerning logging practices.

To date, logging in the boreal forests of Interior Alaska has been relatively small-scale (approximately $400 \mathrm{ha} \mathrm{yr}^{-1}$ ). Thus, impacts on wildlife, both positive and negative, have been relatively minor. However, if industrial level logging operations are to occur in the boreal forests of Alaska as has been proposed (Seidner 1992; Swaffield 1992), management recommendations will have to be based largely upon experiences in other areas such as the western Canadian provinces.

In other areas, efforts to enhance the production of white spruce forest have involved silvicultural practices, such as the use of herbicides, to discourage competing deciduous tree and shrub growth (Daniel et al. 1979). This practice could significantly reduce benefits of logging to early successional wildlife species in Alaska. It is our recommendation that use of herbicides to control deciduous trees not be extensively applied in the boreal forests of Alaska where multiple use of forest resources is a management goal.

$A D F \& G$ is concerned that intensive management for fiber production could lead to short rotation intervals. We recommend, as we did during development of the Susitna Forestry Guidelines (Alaska Department of Natural Resources 1991) in Southcentral Alaska, that a reasonable portion of areas slated for logging be kept on longer rotation lengths to provide suitable habitat for wildlife species requiring large blocks of late successional and mature forest types. Currently, there are no proven guidelines for perpetuation of mixed-wood forests. In Alberta, extensive clearcutting of mixed-wood stands resulted in increased representation of hardwood species and even shifts in representation among the hardwood species (Dancik et al. 1990).

The development of a large-scale logging industry in Alaska would require development of an extensive road network to transport large volumes of raw wood to mills, with direct and indirect impacts on wildlife and wildlife users (Lynch 1973; Scaife 1980; Stelfox 1984). If significant access development is to occur, the ADF\&G recommends the use of winter logging operations and seasonal ice roads to the maximum extent practical to minimize adverse impacts on the land and wildlife.
ADF\&G further recommends that most summer logging roads and trails be physically rendered impassable following logging to avoid the cumulative adverse impacts of high road densities on grizzly bears, marten and other harvest-sensitive species. Where permanent roads are deemed necessary but are found to be having significant and unacceptable adverse impacts on wildlife, we recommend they be managed to discourage high volume private vehicle use, and designed to minimize fish and wildlife impacts (ADF\&G 1991).

Large volume timber extraction for mill operations in the boreal forest involves extensively mechanized logging operations. In Alberta poor reforestation success on some sites (Dancik et al. 1990) has been attributed to the weight and vibration of heavy equipment (Jones and Baltgailis 1993). Such potential impacts of heavy equipment use should be further studied to develop conservation guidelines in the northern boreal forest.

Because many effects of logging can be cumulative, we recommend that timber sales be subjected to full rotational, landscape level planning. All past and future harvesting activities must be evaluated in the context of their cumulative impacts and long term consequences (ADF\&G 1991). Failure to do so has resulted in unacceptable wildlife impacts in other regions and ultimately led to the listing of species under the Endangered Species Act (1973). Subsequent management actions to recover listed species have threatened timber-based local economies.

If managers are to optimize benefits from the boreal forest in Alaska, there are professional, political, economic and biological challenges which will confront both foresters and wildlife biologists. The professional challenge is to integrate our disciplines and accept a broader mission for the management of the boreal forest ecosystem to meet the diverse, evolving needs of society. To insist on a "business as usual" approach to timber extraction is to destine forest management to failure in the future. Professionals must accept growing public interest in forest management and involve the public in decision-making processes. In this manner, strong public support can be developed for integrated forest and wildlife management plans.

The political challenge is to overcome the severe credibility problem which exists among a growing segment of the public who view industrial-scale logging as a serious threat to other forest-related values and the forest itself (Dawe et al. 1994). This distrust is causing people to oppose nearly all timber harvests, even when they may be biologically sound and necessary to address past mistakes (Taylor 1994, Thomas 1994), such as the attempted exclusion of natural fire from the boreal forest in Interior Alaska. The challenge for managers will be to show the public how logging, particularly clearcut logging, can be used responsibly in the boreal forest to mimic natural forces where naturally occurring fires cannot be allowed.

Economics present an additional challenge for managers. Many non-timber forest values are not easily quantified into dollars and cents, and often are not included in the more narrowly defined world of forest management economics. The problem for wildlife managers and foresters interested in forest ecosystems is that timber harvest modifications to accommodate or enhance other values frequently reduce the efficiency of timber harvest operations, add new costs and reduce profit margins. The economic challenge will be to accurately evaluate all forest values and to plan for forest management 
which will result in sustained and, more importantly, stable and diverse economic values from managed forests through the long term.

Biological considerations are a challenge when sufficient information is lacking to reliably predict the consequences of management decisions. This is particularly true if those consequences have the potential to be unacceptable to the publics being served. Knowledge gaps can become critical when managers are forced to push the upper limits of timber harvest from the forest. This is why wildlife biologists urge a cautious flexible approach, especially in the northern reaches of the boreal forest where less is known about relationships between logging and wildlife (Butler 1992).

$A D F \& G$ looks toward the future with a mixture of optimistic enthusiasm and cautious apprehension. We see opportunities to use logging and prescribed burning to maintain or enhance certain wildlife populations. However, we have valid concerns about some recent proposals. The scale at which logging and practices designed to maximize fiber harvests are applied will determine their ultimate impact on wildlife in the boreal forest.

To wildlife, the forest is habitat. ADF\&G urges that decisions concerning future management of the boreal forest be made carefully, based on the best environmental science available and with full public and agency involvement. Timber harvest plans and policies must remain flexible so that new knowledge can be integrated into future decision-making. Collectively, professionals must do the best possible job of managing the boreal forest if they are to provide maximum benefits to the people, and stability and diversity to the economy of Alaska.

\section{References}

Alaska Department of Fish and Game. 1991. Fish and wildlife resources, and forest management recommendations for the Susitna Forestry Guidelines area. Unpub. rep., Hab. and Rest. Div., Anchorage, AK.

Alaska Department of Natural Resources. 1991. Susitna Forestry Guidelines. Div. of Land, Anchorage, AK. 93 p.

Alaska Interagency Fire Management Council. 1993. Alaska Consolidated Interagency Fire Management Plan (draft). 91 p.

Butler, J. 1992. Canadian boreal forests: the great unknown. In: W. Can. Wilderness Comm., Alberta Branch Educ. Rep. 11(7). 8 p. Collins, W.B. 1993. Harvesting birch-spruce forest to enhance moose habitat in the Matanuska Valley Moose Range. ADF\&G, Fed. Aid in Wildl. Rest. Res. Prog. Rep., Proj. W-24-1, Juneau, AK. 11 p. Dancik, B. (chair), L. Brace, J. Stelfox and B. Udell. 1990. Forest management in Alberta - report of the Expert Review Panel. Alberta Energy/For., Lands and Wildl., Pub. \#I/340. 128 p. Daniel, T.W., J.A. Helms and F.S. Baker. 1979. Principles of silviculture. McGraw-Hill Book Co. New York. 500 p.

Dawe, J., A.N. Whitworth, R.J. McCaffrey and D.A. Yates (Eds.). 1994. Voices of the forest: public testimony on the future of the Tanana Valley State Forest. From the series: Issues and opportunities related to land use management in Interior Alaska. Alaska Boreal Forest Council, Fairbanks. 107 p.

Foote, M.J. 1983. Classification, description, and dynamics of plant communities after fire in the taiga of Interior Alaska. USDA For. Serv., Pac. NW For. and Rge. Exp. Sta., Res. Paper PNW-307. 108 p.
Hammond, H. 1992. Seeing the forest among the trees - the case for wholistic forest use. Polestar Press Ltd., Vancouver, BC. 309 p.

Jones, G. and K. Baltgailis. 1993. A new leaf. W. Can. Wilderness Comm., Edmonton, AB. 55 min. video.

Kelleyhouse, D.G. 1979. Fire-wildlife relationships in Alaska. Pp. 1-36 In: Proc. of Workshop Wildlife and Wild Fire. M. Hoefs and D. Russell (Eds.). Yukon Wildl. Branch, Whitehorse, Canada. 2728 Nov. 205 p.

Kelsall, John P., E.S. Telfer and T.D. Wright. 1977. The effects of fire on the ecoogy of the boreal forest, with particular reference to the Canadian north: a review and selected bibliography. Can. Wildl. Serv. Occas. Paper no. 32. 58 p.

LeResche, R.E., R.H. Bishop and J.W. Coady. 1974. Distribution and habitats of moose in Alaska. Naturaliste Can. 101: 143-178. Lynch, G.M. 1973. Influence of hunting in an Alberta moose herd. Proc. No. Amer. Moose Conf. and Workshop 9: 123-135.

Mallik, A. 1992. The role of fire in the boreal forest. In: Boreal biofacts: An introduction to the boreal forest ecosystem. Earthroots, Toronto, ON. 4 p.

Mech, L.D., S.H. Fritts, G.L. Radde and W.J. Paul. 1988. Wolf distribution and road density in Minnesota. Wildl. Soc. Bull. 16: 85-87. Scaife, B. 1980. The impact of forestry practices on moose (Alces alces) in north-central Manitoba. M.S. Thesis, Univ. Manitoba, Winnepeg, MB. $70 \mathrm{p}$.

Seidner, M.A. (President). 1992. Letter to Governor Walter J. Hickel. FibreForm Wood Products Inc., Los Angeles, California. 2 June.

Stelfox, J.G. 1984. Effects of clear-cut logging and scarification on wildlife habitats in west-central Alberta. Can. Wildl. Serv., Edmonton, AB. 176 p.

Swaffield, D.E. 1992. Proposal in support of an application to build an O.S.B. plant in the vicinity of Fairbanks, Alaska. Louisiana-Pacific Corp.

Taylor, R. 1994. Fires spur harder look at logging — bigger timber harvest mulled; environmentalists are wary. Seattle PostIntelligencer. p. A3 In: Anchorage Daily News, Alaska. 30 Aug. Telfer, E.S. 1972. Forage yield and browse utilization on logged areas in New Brunswick. Can. J. For. Res. 2: 346-350.

Thomas, J.W. 1994. Concerning the health and productivity of the fire-adapted forests of the Western United States. Statement presented before: The Subcomm. on Agr. Res., Conservation, For. and Gen. Leg., Comm. on Agr., U.S. Senate, Boise, ID. 29 Aug.

Thompson, I.D. 1994. Marten populations in uncut and logged boreal forests in Ontario. J. Wildl. Mgmt. 58(2): 272-280.

Vallee, J., R. Joyal and R. Couture. 1976. Observations in regeneration of food species for moose in clearcut stands in Mastigouche Park, Quebec. Proc. No. Amer. Moose Conf. and Workshop 9: 54-69. Viereck, L.A. 1973. Ecological effects of river flooding and forest fires on permafrost in the Taiga of Alaska. Pp. 60-67 In: Permafrost: The N. Amer. contribution to the 2nd. Intern. Conf. Nat. Acad. of Sci. Washington, DC.

Viereck, L.A. and L.A. Schandelmeier. 1980. Effects of fire in Alaska and adjacent Canada - a literature review. USDOI, Bureau of Land Mgmt., Tech. Rep. 6. 124 p.

Welbourn, M.L. 1983. Ecologically based forest policy analysis: fire management and land disposals in the Tanana River Basin, Alaska. Ph.D. Dissertation, Cornell Univ., Ithaca, NY. 230 p. 